\title{
FILIFORM, FUNGIFORM PAPILLAE AND TASTE BUDS: DISTRIBUTION AND AGE CHANGES: A MICROSCOPIC STUDY
}

\author{
Vinubal $S^{1}$
}

${ }^{1}$ Assistant Professor, Department of Anatomy, Government Medical College, Kozhikode.

\section{ABSTRACT}

\section{BACKGROUND}

The organs of taste consists of taste buds- caliculus or gemma gestatorius, located in the lingual papillae.

The aim of this study was to note the number, distribution and age changes of fungiform and filiform papillae and taste buds.

\section{MATERIALS AND METHODS}

The study was conducted on 50 specimens of tongue collected from Department of Forensic Medicine and Labour Room, Medical College, Kozhikode.

\section{RESULTS}

In tip region, fungiform and filiform papillae were observed. The maximum number of 21 papillae per low power field was observed in a 13-week-old foetus. With increasing age, a reduction was noted in the number of papillae per low power field. Filiform papillae were first observed in a 27-week-old foetus and its number increased with age. The number of taste buds per fungiform ranged from 0-2. No significant age change was noted. Secondary papillae were first observed in filiform papillae at the age of 32 years. But in case of fungiform papilla, secondary papillae were present in younger age groups also and their number showed a mild increase with age, although not in all cases.

\section{CONCLUSIONS}

As age advances, there occurs a significant reduction in the number of fungiform papillae per low power field and a significant increase in the number of filiform papillae. Secondary papillae showed a significant positive correlation with age in case of filiform papillae. There was no significant age change in the number of taste buds.

\section{KEYWORDS}

Filiform, Fungiform Papillae, Taste Buds.

HOW TO CITE THIS ARTICLE: Vinubal S. Filiform, fungiform papillae and taste buds: distribution and age changes: a microscopic study. J. Evolution Med. Dent. Sci. 2016;5(79):5905-5910, DOI: 10.14260/jemds/2016/1333

\section{BACKGROUND}

Organs of special senses are highly sophisticated sensory receptors, in which the specific neural receptors are incorporated in a non-neural structure which enhances and refines the reception of incoming stimuli. ${ }^{1}$

Taste buds are numerous on all types of lingual papillae except filiform papillae. ${ }^{2}$ Of these, fungiform papillae are present in the greatest numbers on the tongue and are thought to be correlated to the overall number of taste buds. ${ }^{3}$ In fact, fungiform papillae are the first line of the gustatory apparatus to provide information about taste. ${ }^{4}$

Fungiform papillae appear as mushroom shaped pink or red spots scattered among the filiform papillae. 5 They have a short slightly constricted stalk and a slightly flattened hemispherical upper part. 6 Fungiform papillae have a thin non-keratinised epithelium and a richly vascularised

Financial or Other, Competing Interest: None.

Submission 25-08-2016, Peer Review 17-09-2016,

Acceptance 24-09-2016, Published 03-10-2016.

Corresponding Author:

Dr. Vinubal S.

Assistant Professor,

Department of Anatomy,

Government Medical College,

Kozhikode-673008.

E-mail: meeraajeeshvinu@gmail.com

DOI: $10.14260 /$ jemds/2016/1333 supporting tissue core. ${ }^{1}$ Strawberry or raspberry tongue refers to the appearance in scarlet fever, where there is hypertrophy of fungiform papilla along with changes in filiform papilla. ${ }^{7}$

Filiform papillae appear as short bristles and consist of a dense supporting core and a heavily keratinised surface projection. ${ }^{1}$ They are numerous and are arranged in $\mathrm{V}$ shaped rows that are parallel to the terminal sulcus except at the apex, where they tend to be arranged transversely. ${ }^{5}$ These papillae appear to subserve a purely mechanical function. Their roughness facilitates licking of semisolid foods and they contain afferent nerve endings that are sensitive to touch. ${ }^{8}$ In a pathological condition called geographic tongue, there is rapid loss and regrowth of filiform papillae leading to denuded red patches 'wandering' across the surface of the tongue. And in hairy tongue, there is elongation of filiform papillae with a lack of normal desquamation.7

Taste buds are seen in sections under low power as pale, oval bodies in darker stained epithelium. ${ }^{6}$ They extend from the basal lamina, almost to the surface. ${ }^{6}$ The lifespan of each taste cell is about 10 days in lower mammals, but is unknown for humans. ${ }^{9}$

\section{AIMS AND OBJECTIVES}

1. To note the number and distribution of fungiform and filiform papillae in the tip of the tongue and to look for any age change.

2. To study any change in the location and number of taste buds in fungiform papillae as age advances. 


\section{MATERIALS AND METHODS}

50 specimens of tongue and epiglottis in the age group 0-80 years were collected. Autopsy specimens were collected from the Department of Forensic Medicine, Medical College, Kozhikode. Specimens of still born babies were taken from the Labour Room of Medical College, Kozhikode. Ethical Committee clearance was obtained for the same.

\section{Exclusion Criteria}

1. Post mortem bodies of burns cases.

2. Decomposed bodies.

3. Bodies with severe maxillofacial injuries.

Tissue bits were taken from tip region and fixed in Bouin's fluid overnight. They were then processed using ascending grades of alcohol, cleared in xylene and were embedded in paraffin wax. Sections with 6 microns thickness were taken and stained with haematoxylin and eosin. Ehrlich's haematoxylin was used since it could be kept for years after ripening and gave brilliant nuclear stain. Results of the microscopic study were analysed statistically using Spearman's correlation.

\section{RESULTS}

In the youngest foetus studied (13 weeks), 21 fungiform papillae were observed per low power field. Filiform papillae were observed from the age of 27 weeks (Fig. 3). In foetal specimens, the number of taste buds varied from 0-2 per LPF. However, not more than 1 taste bud was observed per fungiform papilla. No secondary papillae were observed.

Number of papillae per low power field decreased after birth. Connective tissue core of fungiform papilla showed secondary papillae. The number of taste buds varied from 0 $1 /$ fungiform papilla. It was present on top of fungiform papilla. Two taste buds were seen on top of some fungiform papilla from the age of 27 years.

After the age of 30 years, number of filiform papillae increased compared to fungiform papilla (Fig. 6). Secondary papillae were observed in filiform papillae in some cases from 32 years onwards. Number of secondary papillae per fungiform also increased. Taste buds per fungiform papilla varied from 0-2 (Fig. 5).

At the age of sixties and seventies, number of taste buds varied from 0-1. Degenerating taste bud was observed at the age of 12 years (Fig. 4) and 78 years. See Table 1 for details.

\begin{tabular}{|c|c|c|c|c|c|c|}
\hline Age & $\begin{array}{c}\text { No./ } \\
\text { LPF }\end{array}$ & $\begin{array}{c}\text { Fungi- } \\
\text { form }\end{array}$ & $\begin{array}{c}\text { Fili- } \\
\text { form }\end{array}$ & $\begin{array}{c}\text { CT/ } \\
\text { Fung }\end{array}$ & $\begin{array}{c}\text { CT/ } \\
\text { Fil }\end{array}$ & $\begin{array}{c}\text { Taste } \\
\text { Bud }\end{array}$ \\
\hline 13 wks. & 21 & 21 & 0 & 0 & 0 & 1 \\
\hline 14 wks. & 17 & 17 & 0 & 0 & 0 & 1 \\
\hline 20 wks. & 13 & 13 & 0 & 0 & 0 & 1 \\
\hline 21 wks. & 13 & 13 & 0 & 0 & 0 & 0 \\
\hline 23 wks. & 14 & 14 & 0 & 0 & 0 & 0 \\
\hline 27 wks. & 10 & 8 & 2 & 0 & 0 & $2(1 / \mathrm{F})$ \\
\hline 28 wks. & 8 & 5 & 3 & 0 & 0 & 1 \\
\hline 30 wks. & 10 & 10 & 0 & 0 & 0 & 1 \\
\hline 33 wks. & 8 & 7 & 1 & 0 & 0 & 1 \\
\hline 3 yrs. & 5 & 4 & 1 & 2 & 0 & 1 \\
\hline 5 yrs. & 3 & 2 & 1 & 3 & 0 & 0 \\
\hline 9 yrs. & 3 & 1 & 2 & $8^{*}$ & 0 & 1 \\
\hline 10 yrs. & 4 & 2 & 2 & $6^{*}$ & 0 & 1 \\
\hline 12 yrs. & 5 & 2 & 3 & 3 & 0 & $2(1 / F)$ \\
\hline 14 yrs. & 4 & 2 & 2 & 4 & 0 & 1 \\
\hline
\end{tabular}

\begin{tabular}{|l|l|l|l|l|l|l|}
\hline 18 yrs. & 1 & 1 & 0 & 2 & 0 & 1 \\
\hline 19 yrs. & 4 & 3 & 1 & 2 & 0 & 0 \\
\hline 20 yrs. & 3 & 2 & 1 & 3 & 0 & 1 \\
\hline 22 yrs. & 1 & 1 & 0 & 0 & 0 & 1 \\
\hline 24 yrs. & 5 & 2 & 3 & 3 & 0 & 0 \\
\hline 25 yrs. & 3 & 2 & 1 & 2 & 0 & 0 \\
\hline 26 yrs. & 3 & 1 & 2 & 3 & 0 & 0 \\
\hline 27 yrs. & 4 & 4 & 0 & $5 *$ & 0 & 2 \\
\hline 32 yrs. & 5 & 2 & 3 & 3 & 2 & 2 \\
\hline 34 yrs. & 4 & 2 & 2 & 6 & 2 & 1 \\
\hline 36 yrs. & 4 & 2 & 2 & 4 & 0 & 0 \\
\hline 38 yrs. & 5 & 2 & 3 & 2 & 0 & 1 \\
\hline 40 yrs. & 5 & 2 & 3 & 3 & 0 & 1 \\
\hline 43 yrs. & 5 & 1 & 4 & 0 & 0 & 1 \\
\hline 45 yrs. & 3 & 2 & 1 & 4 & 0 & 2 \\
\hline 46 yrs. & 4 & 2 & 2 & 2 & 2 & 0 \\
\hline 47 yrs. & 3 & 0 & 3 & 0 & 3 & 0 \\
\hline 48 yrs. & 4 & 1 & 3 & 2 & 0 & 1 \\
\hline 50 yrs. & 4 & 1 & 3 & 3 & 0 & 0 \\
\hline 52 yrs. & 4 & 1 & 3 & 3 & 0 & 0 \\
\hline 55 yrs. & 5 & 1 & 4 & 3 & 2 & 2 \\
\hline 56 yrs. & 4 & 2 & 2 & 5 & 4 & 0 \\
\hline 58 yrs. & 3 & 1 & 2 & 4 & 0 & 2 \\
\hline 60 yrs. & 3 & 1 & 2 & 3 & 2 & 0 \\
\hline 61 yrs. & 3 & 2 & 1 & 6 & 2 & 0 \\
\hline 62 yrs. & 2 & 0 & 2 & 0 & 3 & 0 \\
\hline 64 yrs. & 2 & 1 & 1 & 2 & 0 & 0 \\
\hline 70 yrs. & 3 & 1 & 2 & 5 & 0 & 0 \\
\hline 73 yrs. & 5 & 2 & 3 & 5 & 2 & 1 \\
\hline 75 yrs. & 5 & 0 & 5 & 0 & 2 & 0 \\
\hline 78 yrs. & 4 & 1 & 3 & 3 & 2 & 1 \\
\hline & & & Table 1 & & & \\
\hline & & & & & & \\
\hline
\end{tabular}

Fungiform $=$ Fungiform papillae/LPF.

Filiform = Filiform papillae per LPF.

$\mathrm{CT} /$ Fung $=$ Connective tissue papillae per fungiform.

$\mathrm{CT} / \mathrm{Fil}=$ Connective tissue papillae per filiform.

Taste bud $=$ Taste buds/LPF.

$1 / \mathrm{F}=1$ taste bud per fungiform

*= minor connective tissue papilla.

\section{Statistical Analysis: Spearman's Correlation}

\begin{tabular}{|c|c|c|c|}
\hline & & & Age \\
\hline $\begin{array}{c}\text { Spearman's } \\
\text { Rho }\end{array}$ & Fungiform & Correlation Coefficient & $-.505^{* *}$ \\
& Papillae & Sig. (2-tailed) & .001 \\
& N & 37 \\
\hline & Filiform & Correlation Coefficient & $.389^{*}$ \\
& Papillae & Sig. (2-tailed) & .017 \\
& N & 37 \\
\hline & Taste Buds/ & $\begin{array}{c}\text { Correlation Coefficient } \\
\text { Sig. (2-tailed) }\end{array}$ & -.311 \\
& LPF & N & 37 \\
\hline & CT Papillae/ & Correlation Coefficient & .085 \\
& Fungiform & Sig. (2-tailed) & .617 \\
& N & 37 \\
\hline & CT Papillae/ & Correlation Coefficient & $.554^{* *}$ \\
& Filiform (2-tailed) & .000 \\
& N & 37 \\
\hline \multicolumn{3}{|c|}{ Table 2 } \\
\hline
\end{tabular}

${ }^{* *}$ Correlation is significant at the .01 level (2-tailed)

${ }^{*}$ Correlation is significant at the .05 level (2-tailed)

Statistical Analysis: Spearman's Correlation

Table 2 
Shows the statistical analysis of the data representing the tip region of the tongue (Excluding foetal specimens).

- There is a significant negative correlation between the number of fungiform papillae per LPF and age.

- There is a significant positive correlation between the number of filiform papillae/LPF and age.

- There is no significant correlation between the number of taste buds and age.

- There is no significant correlation between the number of CT papillae per fungiform and age.

- There is a significant positive correlation between the number of CT papillae per filiform and age.

\begin{tabular}{|c|c|c|c|}
\hline & & & AGE \\
\hline \multirow[t]{5}{*}{$\begin{array}{c}\text { Spearman's } \\
\text { Rho }\end{array}$} & $\begin{array}{l}\text { Fungiform } \\
\text { Papillae }\end{array}$ & $\begin{array}{c}\text { Correlation } \\
\text { Coefficient } \\
\text { Sig. }(2 \text {-tailed }) \\
\mathrm{N}\end{array}$ & $\begin{array}{c}-.862^{* *} \\
.003 \\
9\end{array}$ \\
\hline & $\begin{array}{l}\text { Filiform } \\
\text { Papillae }\end{array}$ & $\begin{array}{c}\text { Correlation } \\
\text { Coefficient } \\
\text { Sig. }(2 \text {-tailed }) \\
\mathrm{N}\end{array}$ & $\begin{array}{c}.584 \\
.099 \\
9\end{array}$ \\
\hline & $\begin{array}{l}\text { Taste buds/ } \\
\text { LPF }\end{array}$ & $\begin{array}{c}\text { Correlation } \\
\text { Coefficient } \\
\text { Sig. }(2 \text {-tailed }) \\
\mathrm{N}\end{array}$ & $\begin{array}{c}.149 \\
.701 \\
9\end{array}$ \\
\hline & $\begin{array}{c}\text { CT } \\
\text { Papillae/Fungiform }\end{array}$ & $\begin{array}{c}\text { Correlation } \\
\text { Coefficient } \\
\text { Sig. }(2 \text {-tailed }) \\
\mathrm{N}\end{array}$ & 9 \\
\hline & $\begin{array}{l}\text { CT Papillae/ } \\
\text { Filiform }\end{array}$ & $\begin{array}{c}\text { Correlation } \\
\text { Coefficient } \\
\text { Sig. }(2 \text {-tailed }) \\
\mathrm{N}\end{array}$ & 9 \\
\hline & Table & & \\
\hline
\end{tabular}

${ }^{* *}$ Correlation is significant at the .01 level (2-tailed)

Table 3

This is the statistical analysis of the data representing the tip region of the tongue (Foetal specimens).

- There is significant negative correlation between the number of fungiform papillae per low power field and age.

- There is no significant correlation between any of the other factors and age.

\begin{tabular}{|c|c|c|}
\hline & & $\begin{array}{c}\text { Ratio of Fungiform/ } \\
\text { Filiform Papillae }\end{array}$ \\
\hline \multirow{3}{*}{ Age } & Pearson Correlation & -.514 \\
& Sig. (2-tailed) & .002 \\
& N & 34 \\
\hline \multicolumn{2}{|c|}{ Table 4 } \\
\hline
\end{tabular}

\section{Table 4}

Shows the statistical analysis of the data representing the ratio of fungiform and filiform papillae seen per LPF with age.

- A significant negative correlation is observed.

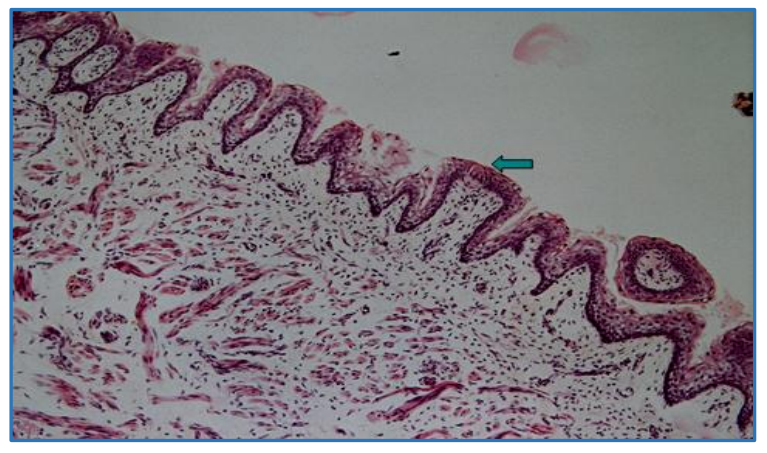

Fig. 1: Section of Tip Region of Tongue of a 13-week-old Foetus showing Fungiform Papilla and Taste Bud (Green Arrow). Haematoxylin and Eosin Staining. Magnification $x 100$

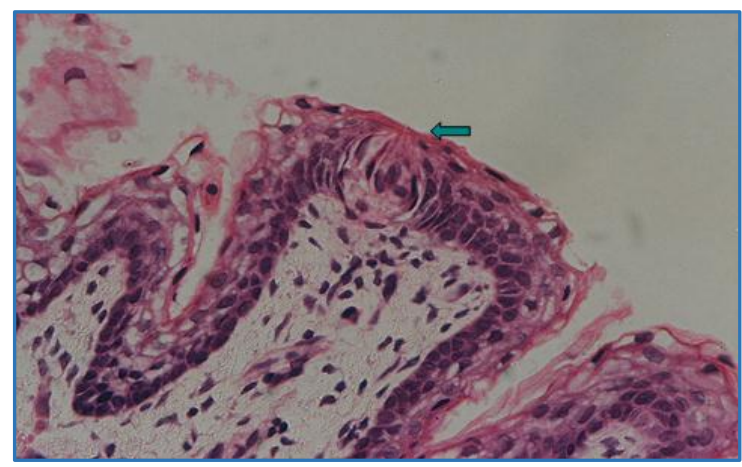

Fig. 2: Section of Tip Region of Tongue of 13-Week-Old Foetus showing Fungiform Papilla and Taste Bud (Green Arrow). Haematoxylin and Eosin Staining. Magnification $x 400$

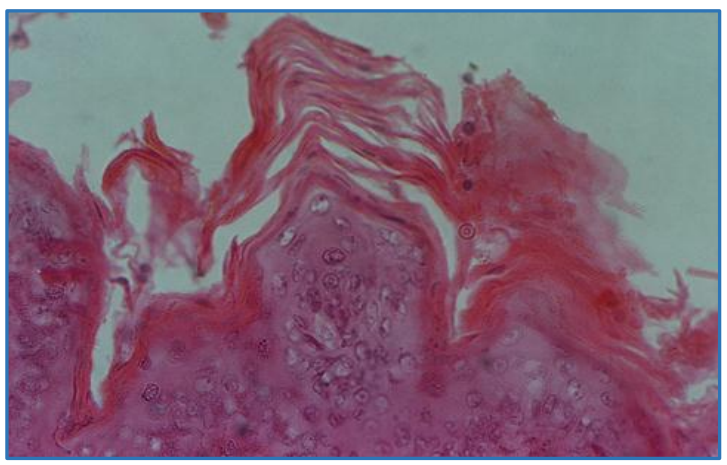

Fig. 3: Section of Tip Region of Tongue of a 27-Week-Old Foetus showing Filiform Papillae with Keratin. Haematoxylin and Eosin Staining. Magnification x 400

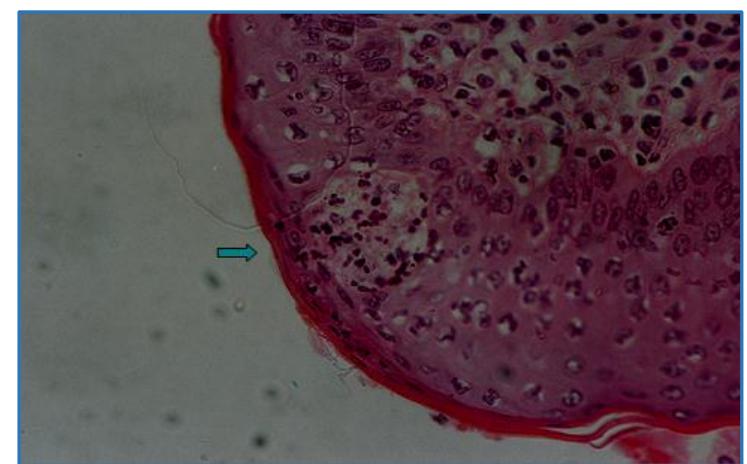

Fig. 4: Section of Tip Region of Tongue of a 12-Year-Old showing Degenerating Taste Bud on Top of a Fungiform Papilla (Green Arrow). Haematoxylin and Eosin Staining. Magnification $x 400$ 


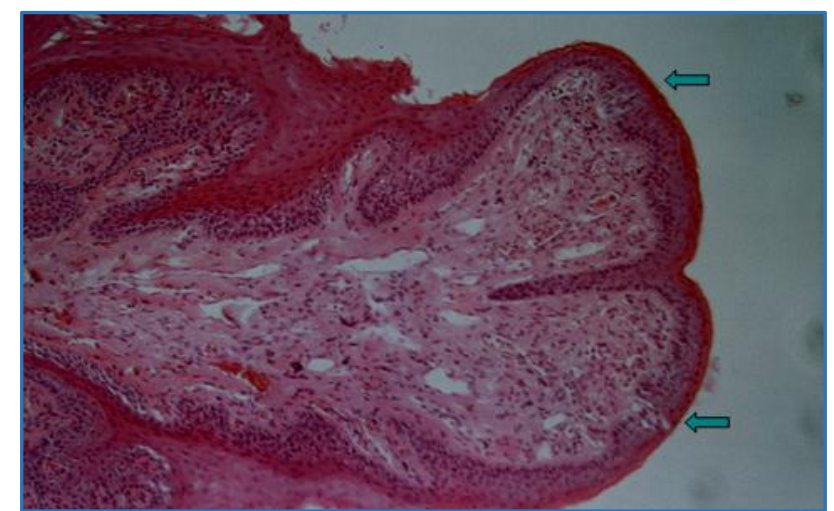

Fig. 5: Section of Tip Region of Tongue of a 45-Year-Old showing 2 Taste Buds on top of a Fungiform Papilla (Green Arrow). Haematoxylin and Eosin Staining. Magnification x 100

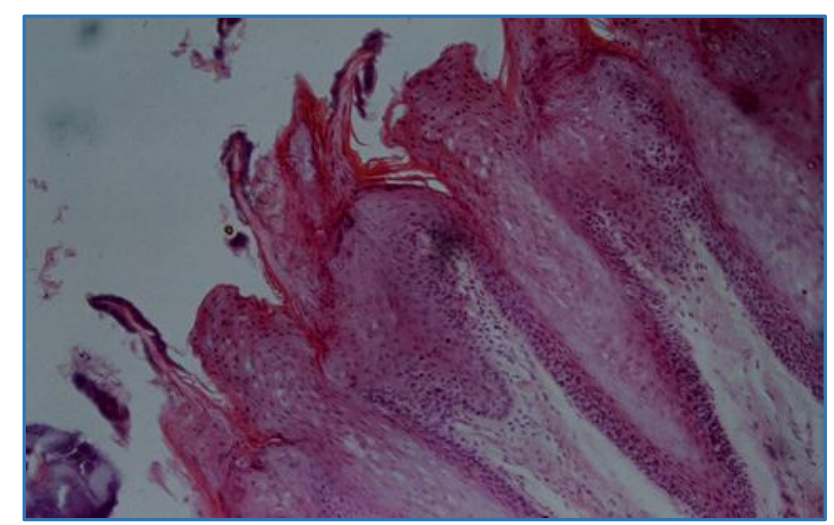

Fig. 6: Section of Tip Region of Tongue of a 75-Year-Old showing Filiform Papillae with Keratin. Haematoxylin and Eosin Staining. Magnification $x 100$

\section{DISCUSSION}

Taste is one of the sensations, which is essential for the existence of man. The robust nature of the peripheral sense of taste in old age appears to be in sharp contrast to other sensory systems.

Though studies on the structure of various papillae and taste buds can be traced back to 1868, most of the works were done on animals. Even now studies on human tissue are few. Observations of this study are discussed under 3 headings.

Fungiform papilla,

Filiform papillae,

Taste buds.

\section{Fungiform Papillae}

Fungiform papillae were observed in the youngest foetus studied (13-week-old).

Fig. 1: This is in agreement with the work of Bradley 196710 and Witt 1997,11 who observed fungiform papillae in 6, 7 weeks old embryo respectively. Before birth, the number of fungiform papillae are more. In this work, maximum number of fungiform papilla was observed in 13-week-old foetus (Table 1). As age advances, there is marked reduction in the number of papillae/LPF. After birth, the number of fungiform papillae per LPF ranges from 1-4 till the age of 32 years. From this age onwards, the number is limited to $0-2 / \mathrm{LPF}$.

Statistical analysis revealed a significant negative correlation between the number of fungiform papillae per LPF and age (Table 2). As age advances, the increase in the number of filiform papillae produces a reduction in the number of fungiform papillae per LPF. This agrees with Fischer (2013),12 who stated that the mean fungiform papillae density was lower for each 5 years increase in age. Just (2003) ${ }^{13}$ found that the density of fungiform papillae varied among the investigated human subjects in different age groups. According to Chen (1998)14 and Konstantinidis (2010),15 the number of fungiform papillae showed no sex related differences. This aspect was not studied.

Becker (1908) ${ }^{16}$ considered fungiform papilla as a primitive type of vallate and foliate papilla. The present study could not find anything to agree with or disagree with the above.

Segovia (2002) ${ }^{17}$ observed increased fungiform papillae densities in children compared to adults. This work does not agree with the above. In the present work, we have noted only 1-2 fungiform papillae/LPF in children aged 5-12 years. According to Correa (2013), ${ }^{18}$ the number of papillae stabilised at 9-10 years of age.

The connective tissue papillae per fungiform papillae were also counted. It was first observed at the age of 3 years. With advancing age, the number of connective tissue papillae showed a mild increase, although not in all cases. Statistical analysis revealed no significant correlation between the number of connective tissue papillae and age (Table 2). This is not in agreement with the work of Kobayashi et al (2001),19 who observed thinning of the connective tissue core with age. However, Kobayashi, also emphasised that there was a great deal of individual variation of human lingual papillae regardless of age.

\section{Filiform Papillae}

Filiform papillae appeared in this study only in 27-week-old foetus (Fig. 3). This does not agree with the work of Witt 1997,11 who observed filiform papillae in a 15-week-old foetus. But it is in agreement with the above study in the fact that filiform papillae appear later in development and the first papilla to develop is fungiform. As this papilla does not have any taste bud, the function of this papilla is not for appreciation of taste. Filiform papillae give a rough surface for the tongue and increase the surface area of the tongue. The keratin makes the surface of the papilla rough and the amount of keratin increase with age. An interesting observation is that the number of filiform papillae increase with age (Fig. 6). When the number of filiform papillae increase, there is a corresponding reduction in the number of fungiform papillae (Table 4). This points to the fact that the filiform papillae by giving roughness to the surface of the tongue allows the food to remain on the tongue, so that taste can be appreciated better. And this may be the reason why old people appreciate taste better than the younger ones. This does not agree with the work of Kobayashi 2001,19 in which a reduction in the number of filiform papillae was observed in old age.

The time of appearance of connective tissue papillae is later in life in case of filiform papilla. In this study, the secondary papillae were first observed at the age of 32 years. The formation of secondary papillae might be to give more stiffness to the papillae. This is supported by the fact that the connective tissue papillae appear very early in life in case of fungiform papilla. The filiform papilla covered with keratin is already stiff and do not require a stiff connective tissue core with secondary papilla. There is no decrease of connective 
tissue papillae as pointed out by Kobayashi $2001 .{ }^{19}$ Instead, a significant positive correlation was noted between the number of connective tissue papillae and age in case of filiform (Table 2).

\section{Taste Buds}

There are various studies done on taste buds. Different cell types are identified by various workers. In this work different types of cells could not be studied, as it is a light microscopic study.

Taste bud was observed in the youngest embryo studied (13 weeks) (Fig. 1). It was present on the upper surface of the fungiform papilla. Of the 21 papillae, taste bud was present on only one. Different types of cells were visible (Fig. 2). Basal cells and cells with elongated nuclei and round nuclei were seen. All were crowded together. This agrees with Bradley (1967), ${ }^{10}$ who stated that morphologically many cells were recognisable at 13-15 weeks.

In fungiform papilla, it was always on the upper surface. This is in agreement with the works of Arvidson (1979) ${ }^{20}$ and Richard O Davies et al (1979). ${ }^{21}$

The number varied between $0-2$ /fungiform papilla (Fig. 5). Never more than 2 were seen. But according to Cheng et al (1991), ${ }^{22}$ average taste buds varied from 0-3.

Arvidson K (1979) ${ }^{20}$ had studied 182 fungiform papillae and had observed taste buds on the dorsal surface. According to him while the number of taste buds in a single papilla varied from $0-27,63 \%$ of the papillae had no taste buds at all, $26 \%$ had 1-3 buds and the remainder 4 or more buds. The mean number of taste buds per papilla varied from 0-9 between individuals and no dependence upon sex or age could be demonstrated for this variation. This work also agrees with the above study, but not more than 2 taste buds per fungiform papilla were seen per LPF. Majority of fungiform papilla showed only one. Degenerating taste bud was observed in the fungiform papilla at the age of 12 years and 78 years.

Statistical analysis revealed no significant correlation between the number of taste buds in the various papillae and age (Table 1). This is in agreement with Saito (2016), ${ }^{23}$ who found that the average number of taste buds was similar among all age groups.

Yamaguchi (2001) ${ }^{24}$ mentioned that the effect of aging on taste bud number was different among individuals and did not simply depend on increasing age. This study agrees with this. Inglis J Miller (1986) ${ }^{25}$ also found wide variations in fungiform taste bud densities in tongues of human cadavers.

Ernest R Lalonde (1961), ${ }^{26}$ stated a clustering effect on taste buds. According to him, taste buds were grouped together. Arey and Monzingo (1942), ${ }^{27}$ attributed the clustering effect "to the innervation of taste buds and the formative influence that nerves had on taste bud development." No such clustering was seen in the present study.

\section{CONCLUSION}

As age advances, there occurs a significant reduction in the number of fungiform papillae per low power field. Secondary papillae in case of fungiform showed no significant change with age, though there was a mild increase.

The number of filiform papillae per low power field shows a significant increase with age. The number of connective tissue papillae of filiform also showed a significant positive correlation with age.

Taste buds observed on top of fungiform papillae varied from 0-2 and showed no significant correlation with age.

\section{REFERENCES}

1. Young B, Lowe JS, Stevens A, et al. Wheater's Functional Histology. A text and colour atlas. Chapter $13,21.5^{\text {th }}$ edn. Philadelphia, USA: Churchill Livingstone Elsevier 2006:258-9, 400.

2. Standring S. Gray's Anatomy. Section 4. Chapter 30. 40th edn. Churchill Livingstone 2008:507-8.

3. Sanyal S, O'Brien SM, Hayes JE, et al. TongueSim: development of an automated method for rapid assessment of fungiform papillae density for taste research. Chem Senses 2016;41(4):357-65.

4. Wockel L, Jacob A, Holtmann M, et al. Reduced number of taste papillae in patients with eating disorders. J Neural Transm (Vienna) 2008;115(3):537-44.

5. Moore KL, Dalley AF, Agur AMR. Clinically oriented anatomy. Head chapter. $6^{\text {th }}$ edn. Philadelphia: Wolters Kluwer Health/Lippincott Williams \& Wilkins 2010;7:940.

6. Bloom and Fawcett. A text book of histology. In: Fawcett DW. Oral cavity and associated glands. Chapter $23.11^{\text {th }}$ edn. 1986:582-6.

7. Durso SC. Oral manifestations of disease. Chapter 45. In: Kasper D, Fauci A, Hauser S, et al. eds. Harrison's principles of internal medicine. Vol 1. Section $4.19^{\text {th }}$ edn. McGraw-Hill Global Education Holdings 2015; P. 241.

8. Moore KL. Clinically oriented anatomy. The Head Chapter. $2^{\text {nd }}$ edn. Baltimore: Williams \& Wilkins 1985; 7:935.

9. Guyton AC. The chemical senses-taste and smell. In: Hall JE. edr. Guyton and Hall textbook of medical physiology. Chapter 53. 12 th edn. Saunders Elsevier 2011:646.

10. Bradley RM, Stern IB. The development of the human taste bud during the foetal period. J Anat 1967;101(Pt 4):743-52.

11. Witt M, Reutter K. Scanning electron microscopical studies of developing gustatory papillae in humans. Chem Senses 1997;22(6):601-12.

12. Fischer ME, Cruickshanks KJ, Schubert CR, et al. Factors related to fungiform papillae density: the beaver dam offspring study. Chem Senses 2013;38(8):669-77.

13. Just T, Gafumbegete E, Kleinschmidt EG, et al. Contact endoscopic quantification of fungiform papillaecorrelation to taste ability?. Laryngo Rhino Otologie 2003;82(7):501-7.

14. Chen N, Yang X, Zuniga JR. Quantitative studies of taste and fungiform papillae on the anterior human tongue. Zhonghua Kou Qiang Yi Xue Za Zhi 1998;33(3):140-2.

15. Konstantinidis L, Chatziavramidis A, Printza A, et al. Effects of smoking on taste: assessment with contact endoscopy and taste strips. Laryngoscope 2010;120(10):1958-63.

16. Becker. Ueber Zungenpapillen. Jenaische Ztschr. f. Naturuiss 1908;43:537-618.

17. Segovia C, Hutchinson L, Laing DG, et al. A quantitative study of fungiform papillae and taste pore density in adults and children. Brain Res Dev Brain Res 2002;138(2):135-46. 
18. Correa M, Hutchinson L, Laing DG, et al. Changes in fungiform papillae density during development in humans. Chem Senses 2013;38(6):519-27.

19. Kobayashi K, Kumakura M, Yoshimura K, et al. Stereo structural study of the lingual papillae and their connective tissue cores in relation to ageing changes in the human tongue. Ital J Anat Embryol 2001:106(2 Suppl 1):305-11.

20. Arvidson K. Location and variation in number of taste buds in human fungiform papillae. Scand J Dent Res 1979;87(6):435-42.

21. Davies RO, Kare MR, Cagan RH. Distribution of taste buds on fungiform and circumvallate papillae of bovine tongue. Anatomical Record 1979;195(3):443-6.

22. Cheng LH, Robinson PP. The distribution of fungiform papillae and taste buds on the human tongue. Arch Oral Biol 1991;36(8):583-9.
23. Saito $\mathrm{T}$, Ito $\mathrm{T}$, Ito $\mathrm{Y}$, et al. Comparison of fungiform taste bud distribution among age groups using confocal laser scanning microscopy in vivo in combination with gustatory function. Eur J Oral Sci 2016;124(2):135-40.

24. Yamaguchi K, Harada S, Kanemaru N, et al. Age related alteration of taste bud distribution in common marmoset. Chem Senses 2001;26(1):1-6.

25. Miller IJ. Variation in human fungiform taste bud densities among regions and subjects. Anatomical Record 1986;216(4):474-82.

26. Lalonde ER, Eglitis JA. Number and distribution of taste buds on the epiglottis, pharynx, larynx, soft palate and uvula in a human newborn. Anatomical Record 1961;140(2):91-5.

27. Arey LB, Monzingo FL. Can hypoglossal nerve fibres induce formation of taste buds?. Quart Bull Northw Univ Med Sch 1942;16:170-8. 